
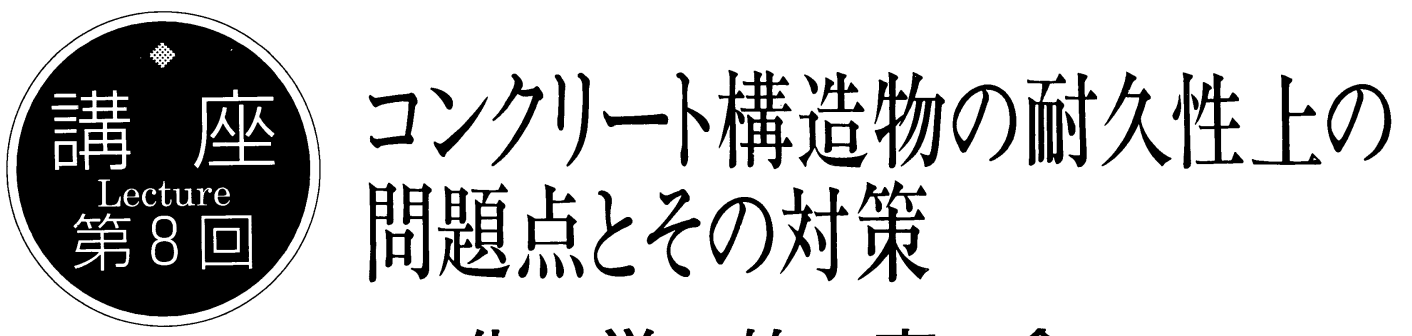

化 学 的 腐 食

坂 井 悦 郎*

1. まえがき

コンクリート構造物の化学的腐食は本来, 化学や食品 工場など諸工業の施設, 海洋環境, 硫酸塩土堹地域や温 泉地域などの特殊な環境において問題とされ，一般的な 環境におけるコンクリート構造物では, それほど重要と されてこなかった。しかしながら, 酸性雨問題や炭酸ガ スによる水和物の分解などが指摘され ${ }^{12}$, また下水処理 施設や下水道などで, 微生物の作用により生成した硫酸 などによるコンクリート構造物の劣化が新たに発見され るなど ${ }^{2)}$, 化学的腐食に関連した問題は拡大しつつあ り, その重要性は増している。さらに, 今後予定されて いる大深度地下空間の開発や既に建設された大規模な地 下構造物である石油備蓄施設や放射性廃棄物処理施設な どでは, コンクリート構造物は常に地下の腐食性物質を 含む環境にさらされることになる。このような地下空間 を利用した社会資本の維持などと関連しても，コンク リート構造物の化学的腐食は重要な問題となるものと思 われる。

本講座で取り扱うコンクリート構造物の化学的腐食と は, 何らかの化学反応が伴いコンクリートに変状を来す ことで, 水和物の分解, 膨張性化合物の生成や水和物の 溶脱等を伴いコンクリートが劣化することを言う。ここ では各種の有機・無機酸, 硫酸塩や塩化物, 腐食性ガ ス, 微生物および炭酸ガスによるコンクリートの劣化を 取りあげ, その劣化機構や問題点, およびこれら化学的 腐食に対する対応策などについて概説する。

\section{2. 化学的腐食因子亡劣化機構}

図-1に対象構造物之化学的腐食因子, およびそれを 支配する主な劣化機構をまとめた。

\footnotetext{
* さかい・えつお/東京工業大学助教授 工学部 無機材料 工学科 (正会員)
}

地下空間に建設される施設については, 特に構造物が 置かれる環境がより硫酸塩土壤地域に変化してきてお り, この際硫酸塩の作用によりコンクリート中に膨張性 成分であるエトリンガイトが生成し, 最終的には膨張破 壊に至る。同様なものとしては海水の作用を受ける海洋 環境があるが, この場合には硫酸塩に加えて塩化物の作 用が重要になる。塩化物は鉄筋の腐食を促進するが, こ れは本講座の「塩害」の項で取り扱われている。なお, 塩化物でもマグネシウム塩や濃厚溶液においては水和物 の変化を伴うなどの化学的腐食が進行している。

化学工業や食品工業を初めとして諸工場施設において は, コンクリートは図中のほとんどの化学的腐食を受け ることになる。また, 近年注目されている酸性雨も, 今 後はさらに問題となる地域が拡大することが想定され, 炭酸ガスによる水和物の分解はすべてのコンクリート構 造物が対象となる。わが国の温泉の主成分は非常に種類 に富んでおり, コンクリートの化学的腐食因子も酸, 硫 酸塩, 塩化物, 重炭酸塩および硫化水素など多岐にわた る。また, 下水道・下水処理施設においては硫化水素ガ ス, 微生物により生成した硫酸, 硫酸塩さらには炭酸ガ スによる腐食などが問題となる。

さらに, わが国でも融雪剤の使用量が増加しており, 特にこれら使用地域においては濃厚な塩化物溶液にコン クリート構造物がさらされることになり, 著しい劣化を 伴う場合もある。

以上のようにコンクリートの化学的腐食には, 水和物 の分解を伴うものとして有機・無機酸, 動植物油, 腐食 性ガス, 炭酸ガスおよび硫酸の生成を伴う微生物の作用 がある。また，膨張性化合物を生成するものとしては動 植物油, 硫酸塩, 海水およびアルカリ濃厚溶液の作用が あり, 水和物の溶脱により硬化体が多孔化するものとし ては濃厚な塩化物溶液や硝酸塩溶液の作用が挙げられ る。これらコンクリートの化学的腐食の主なものについ 


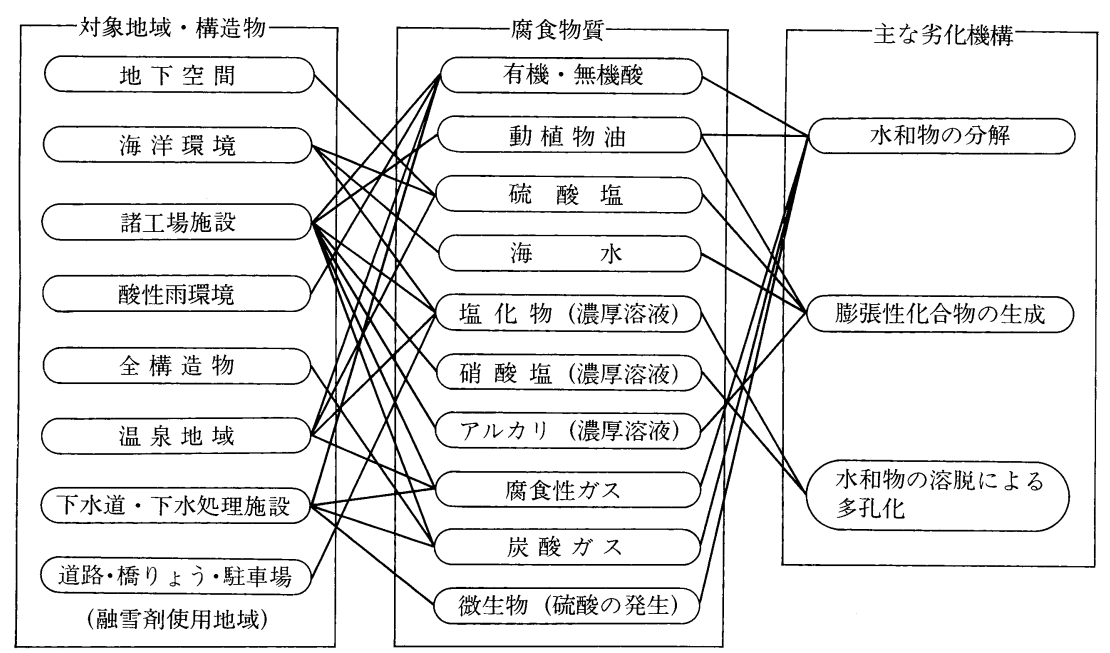

図-1 コンクリート構造物の環境之腐食物質

て酸による腐食, 硫酸塩による腐食, 塩化物による腐 食, 炭酸ガスによる腐食およびその他の腐食等に大別 し，以下に概説する。

\section{1 酸による腐食}

図-2に各種の酸に浸漬した普通セメントモルタルの 重量減少を示した ${ }^{3)}$ 。塩酸, 硝酸および硫酸などの無機 および酶酸や乳酸などの有機酸水溶液中に浸漬されたコ ンクリートは，いずれの場合も $1 \%$ 以上の濃度ではコ ンクリートの重量は著しく減少し，酸に対する完全な抵 抗性をコンクリートに期待することは難しい。水和物と 酸との反応生成物の溶解度が高いものほど著しく浸食さ れる傾向にあり, 塩酸, 硝酸のほうが硫酸より低濃度か ら浸食が開始されている。

硫酸と各種セメント水和物の反応生成物について検討 を加えた一例を表-1 に示す ${ }^{4)}$ 。いずれの反応も急激に 進行し, 水酸化カルシウムは石こうに, $\mathrm{C}-\mathrm{S}-\mathrm{H}$ は石こ うとシリカゲル，エトリンガイトは石こうと硫酸アルミ

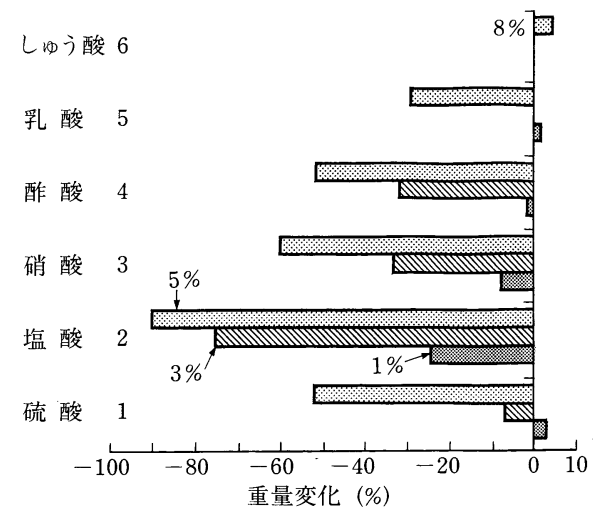

図-2 モルタルの酸溶液中の重量変化
表-1 各種セメント水和物と硫酸の反応生成物

\begin{tabular}{ll}
\hline \multicolumn{1}{c}{ Hydrates } & \multicolumn{1}{c}{ Reaction Products } \\
\hline $\mathrm{Ca}(\mathrm{OH})_{2}$ & $\mathrm{CaSO}_{4} \cdot 2 \mathrm{H}_{2} \mathrm{O}$ \\
$\mathrm{AFt}$ & $\mathrm{CaSO}_{4} \cdot 2 \mathrm{H}_{2} \mathrm{O}, \mathrm{Al}_{2}\left(\mathrm{SO}_{4}\right)_{3} \cdot \mathrm{nH}_{2} \mathrm{O}$ \\
$\mathrm{AFm}$ & $\mathrm{CaSO}_{4} \cdot 2 \mathrm{H}_{2} \mathrm{O}, \mathrm{Al}_{2}\left(\mathrm{SO}_{4}\right)_{3} \cdot \mathrm{nH}_{2} \mathrm{O}$ \\
Tobermorite & $\mathrm{CaSO}_{4} \cdot 2 \mathrm{H}_{2} \mathrm{O},\left(\mathrm{SiO}_{2}\right)$ \\
Xonotlite & $\mathrm{CaSO}_{4} \cdot 2 \mathrm{H}_{2} \mathrm{O},\left(\mathrm{SiO}_{2}\right)$ \\
C-S-H & $\mathrm{CaSO}_{4} \cdot 2 \mathrm{H}_{2} \mathrm{O}, \mathrm{SiO}_{2}$ gel \\
\hline
\end{tabular}

ニウムに分解する。このような分解生成物である石こう などの溶解度が低いために他の酸より若干浸食は遅い

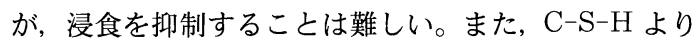
かなり結晶性の良い水熱反応により合成した水和物であ るトバモライトやゾノトライトでも簡単に硫酸と反応し 分解しており，水和物自体の酸に対する抵抗性を改善す ることは困難である。

有機酸についてもカルシウム塩の溶解度の低いしゅう 酸は, カルシウム塩の溶解度の高い酢酸, 乳酸などに比 べて浸食されにくくなっているが，有機酸によってもコ ンクリートの侵食は進行する。

なお，酸性雨を対象として模擬的な $\mathrm{pH} 4$ 程度の酸に 対する研究では，コンクリートはほとんど浸食作用は受 けないとする報告もある ${ }^{5)}$ 。

動植物油においては，その種類により含まれる量は大 きく異なるが，遊離の脂肪酸が含まれる。これら酸によ る水和物の分解之, さらには動植物油の場合において は, 脂肪酸のグリセリンエステルがセメント硬化体中の 水酸化カルシウムの作用により加水分解し, 脂肪酸カル シウムを生成する際に膨張を生じることもコンクリート の劣化の原因とされている ${ }^{3)}$ 。

酸によるコンクリートの化学的腐食の特殊な実例とし て, 下水道や下水道施設がある。 


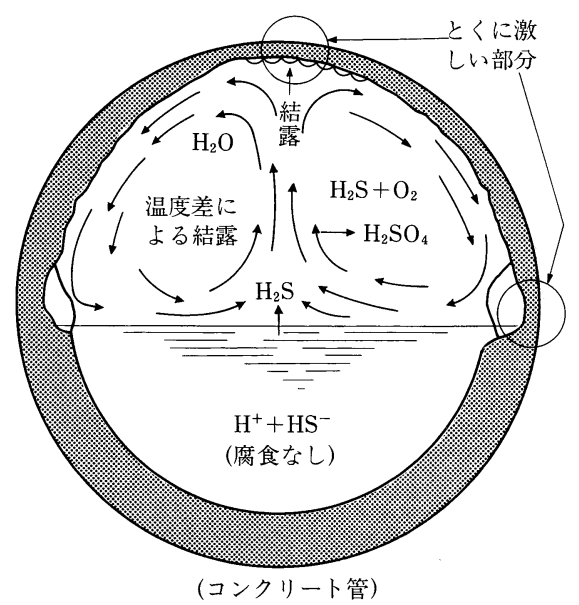

図一个 下水管の腐食

下水管の腐食状況は図-3 のごとく模式化されてお $り^{2}$ ，下水面下の嫌気部分は腐食せず，水面上の管壁が 腐食している。嫌気的な条件で硫酸塩還元細菌により硫 化水素がつくられ, 次式のように好気的条件下でイオウ 酸化細菌により硫化水素が硫酸に酸化され, 酸による腐 食が進行する。

硫化水素 $\rightarrow$ 元素イオウ+水素

元素イオウ+酸素 + 水 $\rightarrow$ 亜硫酸

チオ硫酸 $\rightarrow$ 元素イオウ + 亜硫酸

亜硫酸 + 水 $\rightarrow$ 硫酸 + 水素

\section{2 硫酸塩による腐食}

硫酸塩によるセメントコンクリートの劣化機構は,
表-2 のごとく，一般的な硫酸塩，硫酸マグネシウムお よび海水の作用として分類しまとめることができる ${ }^{6)}$ 。 一般的な硫酸塩による侵食機構としては硫酸イオンの硬 化体内部への拡散と水酸化カルシウムとの反応による石 こうの生成, さらに最終的にはエトリンガイトを生成 し，セメント・コンクリートは膨張破壊する。一方, 硫 酸マグネシウムではカルシウムシリケート水和物にも影 響を与え, モノサルフェート水和物と両者が分解すると している。また，水酸化カルシウムは反応し石こうを生 成して, エトリンガイトの生成による膨張破壊も生じる ことになる。

海水の作用する鉄筋コンクリート構造物を考えた場合 には, 塩化物イオンの拡散のほうが硫酸イオンに比べて 速く, 鉄筋を腐食させることのほうが問題である。化学 的腐食に関連する反応のほうからも最初にフリーデル氏 塩を生成し, その後, 後から拡散した硫酸イオンとの反 応によりエトリンガイトを生成して膨張破壊にいたる。

\section{3 塩化物による腐食}

塩化物のなかでも, 塩化マグネシウムによるコンク リート構造物の化学的腐食が問題とされている。以下の ように硬化体中の水酸化カルシウムが塩化マグネシウム と反応し, 塩化カルシウムを形成して, 細孔量を著しく增 加させ, それが塩化マグネシウム溶液中でモルタルコン クリートが強度を低下させる原因と説明されている7 。 なお, 塩化アンモニウムや硝酸塩も同様に水酸化カルシ ウムの溶脱による多孔化が生じると報告されている3）

表-2 硫酸塩によるセメントコンクリートの劣化機構

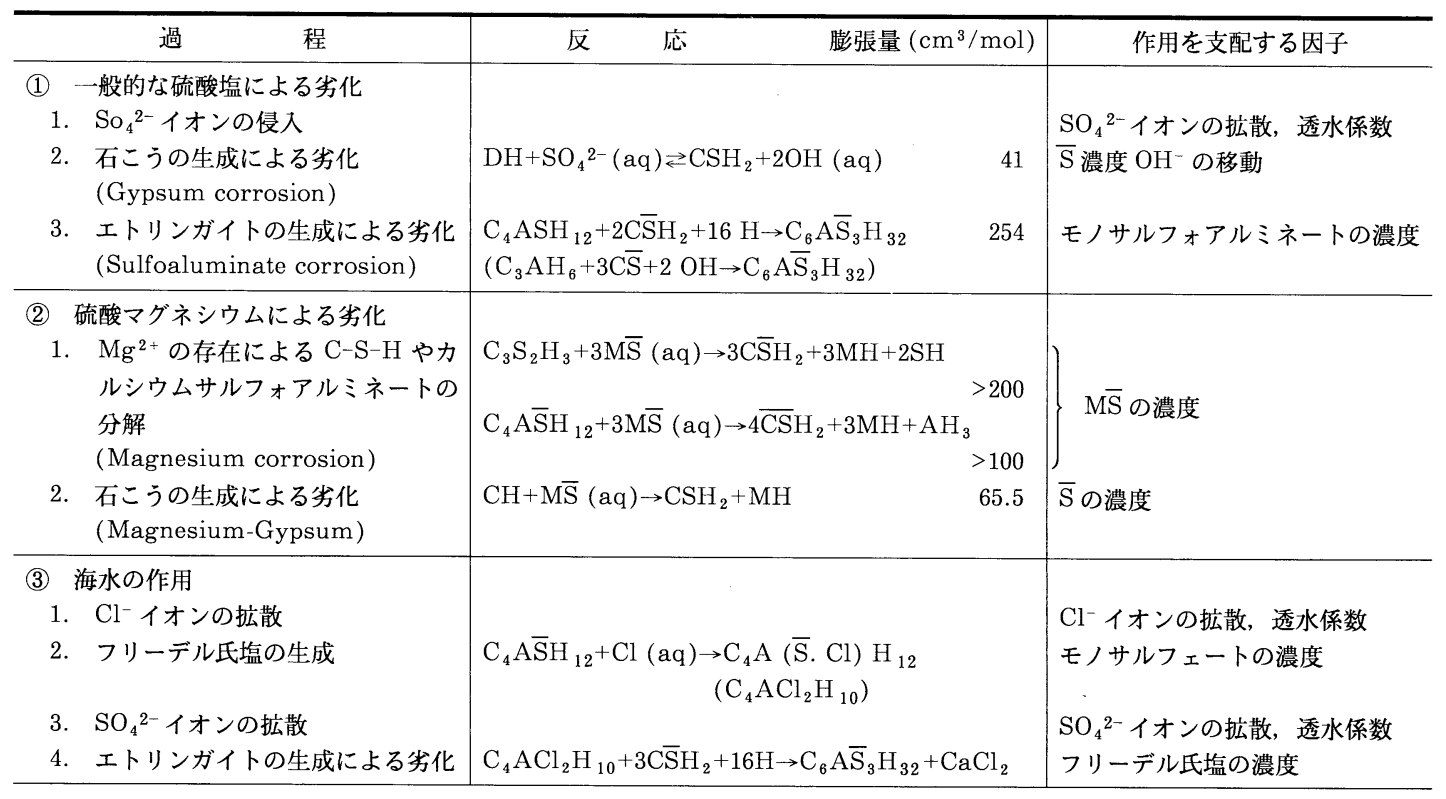




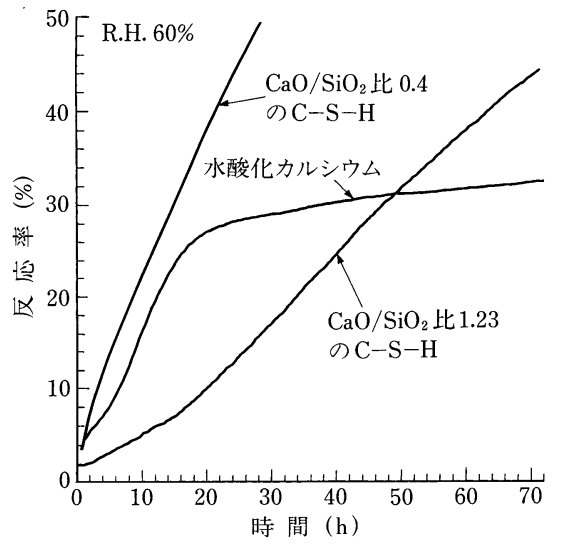

図-4 相対湿度 $60 \%$ における水酸化カル シウム, ケイ酸カルシウム水和物の炭 酸化反応率

$\mathrm{Ca}(\mathrm{OH})_{2}+\mathrm{MgCl}_{2} \rightarrow \mathrm{Mg}(\mathrm{OH})_{2}+\mathrm{CaCl}_{2}$

（硬化体中（侵食液）（表面に析出）（溶出）

の水和物)

他の塩化物についてコンクリートが化学的腐食を受け る事例は報告されていなかったが, 最近 $30 \%$ 程度の塩 化カルシウム濃厚溶液でもモルタルコンクリートが劣化 する現象が報告されている ${ }^{8)}$ 。

\section{4 炭酸ガスによる腐食}

従来より炭酸ガスによるコンクリート構造物の劣化 は, 中性化による鉄筋の腐食として議論されてきた。し かし, 炭酸ガスによる水和物の分解による強度低下の恐

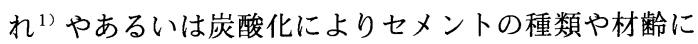

よっては硬化体が多孔化する ${ }^{9)}$ などの問題点が指摘さ れ, コンクリートの化学的腐食の問題としても重要に なってきている。図 -4 は, 各種水和物の炭酸ガスとの 反応率を炭酸ガス吸収量から求めたものである。これは $10 \%$ の炭酸ガス濃度を用いて湿度 $60 \%$ で促進炭酸化 試験を実施した場合の一例である ${ }^{10}$ 。水酸化カルシウム は，ある時期より炭酸化反応が拡散律速になり反応速度 は急激に小さくなる。これに対し，C-S-H の炭酸化反 応は継続的に徐々に進行する。特に $\mathrm{Ca} / \mathrm{Si}$ 比が小さな ものほど炭酸化反応が急激に進行することが明らかに なっている。このような水和物は，ポゾランや潜在水硬 性物質を多量に混和した場合に生成するので，そのよう な場合は特に炭酸ガスとの反応による化学的腐食には注 意をする必要がある。このような炭酸ガスと水和物の反 応は湿度の影響を大きく受け ${ }^{10)}$, 必ずしも実際の構造物 の現象と全てが対応するわけではないが，炭酸ガスとの 反応による水和物の分解もコンクリートの重要な化学的 腐食の一つと考えることができる。

\section{5 その他の物質による腐食}

強アルカリによる劣化としては, 水和物の溶解やアル カリ骨材反応の促進などが指摘されている。また, 腐食 性ガスによるものとしては硫化水素, 亜硫酸ガス, フッ 化水素や塩化水素などがある。いずれも酸を生成するこ とになり酸による劣化機構と同一と考えられる。

3. 化学的腐食の防止

図一 5 にコンクリートの化学的腐食に対する防止策を まとめた。コンクリートに対する化学的腐食の程度が強

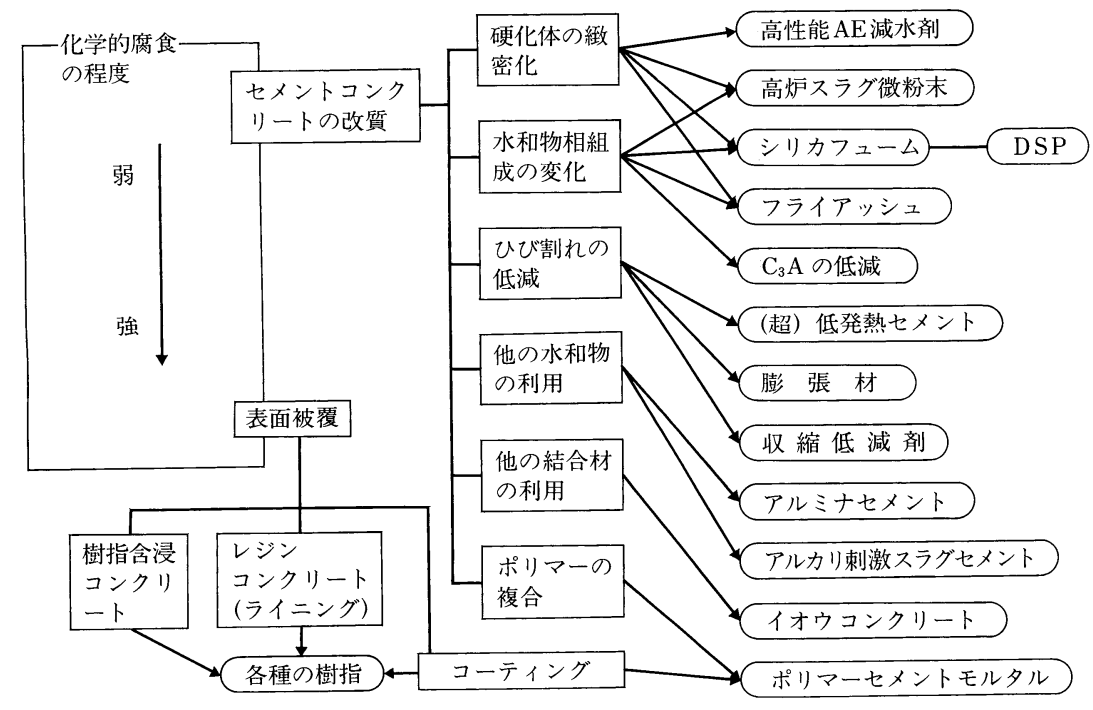

図-5 コンクリートの化学的腐食に対する防止策 
い場合と弱い場合により化学的腐食に対する防止策は異 なり, ある程度の化学的腐食はセメント・コンクリート の改質により対応が可能であるが, 化学的腐食が強い場 合には表面被覆などでの対応が必要となる。なお, 化学 的腐食の強さの程度は供用期間との組み合わせから決定 されるので, 具体的に数值化することは難しいが, 次の 例などは参考になる ${ }^{11}$ 。

例えば, 下水道関係では硫化水素から生成する硫酸に より腐食を受ける重度の対策が必要な箇所と, 炭酸によ り中程度の劣化を受ける箇所, 下水中の硫酸塩や炭酸ガ スによる中性化を受ける軽度の対策が必要な箇所に分類 しそれぞれの対応策を整理している。軽度の対策はセメ ントコンクリートの改質により防食効果を得ることが可 能であるが, 重度の場合にはセメントコンクリートの改 質で対応するのは難しく, 表面被覆を実施することとし ている。中程度においては, どの程度の期間の供用を期 待するかによりどちらの防食方法を選定するか決まる。

セメントコンクリートの改質に関しては, 硬化体を緻 密化させることは腐食因子の浸透を防止する点から重要 である。これには高性能 $\mathrm{AE}$ 減水剤などの使用により 作業性を確保し, 水セメント比を低下させることや, 潜 在水硬性物質の高炬スラグ微粉末 ${ }^{22}$ やポゾラン物質の フライアッシュやシリカフューム ${ }^{13)}$ の利用がある。さ らには, シリカフュームなどの超微粒子と高性能減水剂 の使用により水結合材比を著しく低下させた DSP コン クリートは, 流し込み成形できる最も緻密なセメントコ ンクリートといえる。図-6に無機・有機酸に対する DSP モルタルの試験結果を普通モルタルの場合と比較 して示した ${ }^{14}$ 。DSP モルタルは無機・有機いずれの酸 に対する抵抗性も向上し, エポキシ樹脂と同程度の抵抗 性を有している。これはシリカフュームを用いた DSP では硬化体中の細孔量が著しく減少し, さらに水和物の

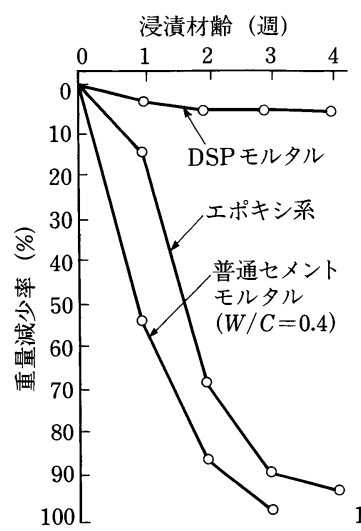

(a) $30 \%$ 酢酸

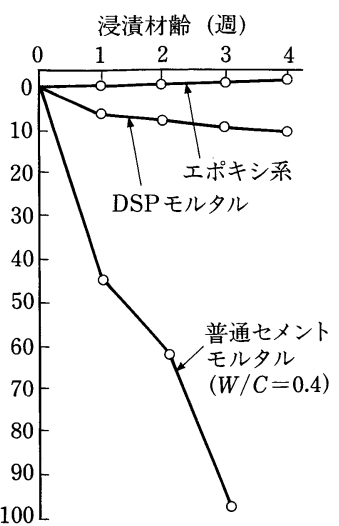

(b) $30 \%$ 塩酸
図-6 DSP モルタルの耐酸性
中では溶解度の高い水酸化カルシウム量も減少するため である ${ }^{14}$ 。

硫酸塩に対する抵抗性を向上させるためには，エトリ ンガイトの生成を抑制させることを目的に $\mathrm{C}_{3} \mathrm{~A}$ 量を減 少させた耐硫酸塩セメントが実用され, 高炉スラグ, フ ライアッシュやシリカフュームの利用も耐久性を向上さ せる。 $\mathrm{C}_{3} \mathrm{~A}$ 量を減少させることはエトリンガイトの生 成量を減少させるためと説明されているが, 逆に $\mathrm{C}_{4} \mathrm{AF}$ 量は増加しており, これらの水和物は膨張性を示さない ためとの報告もある ${ }^{6)}$ 。なお, 海水など塩化物イオンが 共存するような作用の場合には塩化物イオンを固定化さ せる能力が低下しており, 塩化物イオンの内部への拡散 を早め鋼材の腐食を早めることも考えられるので, 両者 の関係を十分考慮して選択する必要がある。

なお, コンクリート構造物の化学的腐食に対する抵抗 性を向上させるためには, ひび割れを抑制することは重 要なことである。マスコンクリートの場合には三成分系 や高ビーライトセメント系の低発熱セメントの利用が考

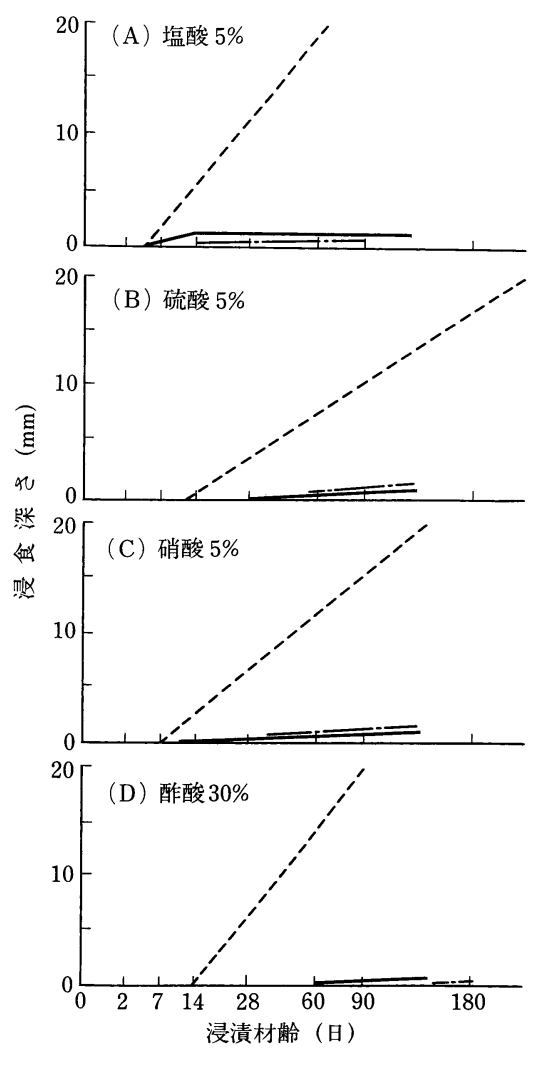

図-7 アルカリ刺激スラグセメントの各種 酸に対する侵食深さ（破線：普通セメ ント, 実線 : アルカリ刺激スラグセメ ント) 


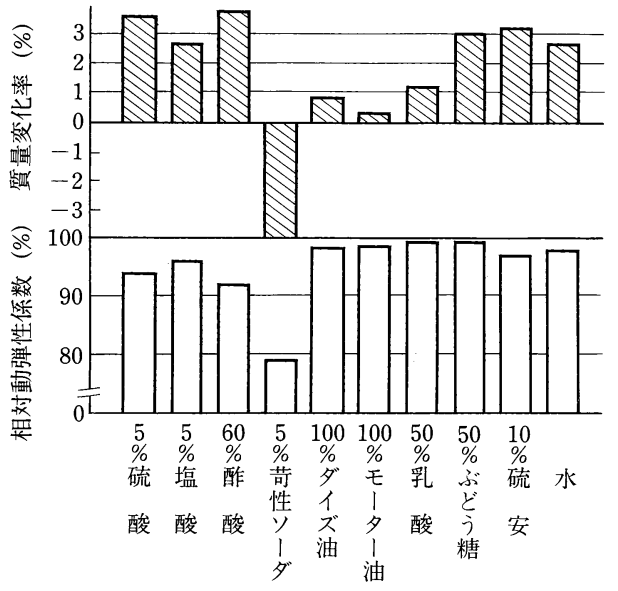

図-8 各種酸性溶液中のイオウコンクリートの変 化 (3 か月)

えられる。また, 膨張材やアルキレンオキシシド共重合 体など ${ }^{15)}$ を主成分とする収縮低減剤を利用し, 乾燥収 縮を減少させることも重要なことである。

酸の作用についてはアルミナセメントなどのように, ポルトランドセメント系とは異なる水和物を生成させる ことにより高めることができる ${ }^{16)}$ 。また，アルミナセメ ントに石灰石微粉末の併用は耐硫酸塩に対する抵抗性を 向上させるとされている ${ }^{17}$ 。

アルカリ刺激スラグセメントのようにポルトランドセ メントを全く含まない場合にも, 図一7のように各種酸 に対する抵抗性は高まる ${ }^{18)}$ 。このようにポルトランドセ メント系でないセメントの利用は耐化学的腐食性から重 要である。ただし, アルミナセメントにおいては, 水和 物の転化すなわち $\mathrm{C}_{3} \mathrm{AH}_{6}$ に変化することによる強度低 下や炭酸ガスにより中性化しやすいこと, また, アルカ リ刺激スラグセメントにおいても中性化に対する抵抗性 や耐摩耗性が低いことなどを十分理解して利用する必要 がある。アルミナセメントを利用した DSP は安定な水 和物である $\mathrm{C}_{3} \mathrm{AH}_{6}$ を生成しても高い強度を示すことが 報告されており, 化学的腐食に対する抵抗性が期待され る。

他の結合材を利用したものとしてイオウコンクリート があり,図-8に示すごとくセメントコンクリートが侵食
される酸に対する抵抗性が優れているとされている ${ }^{19)}$ 各種のポリマーラテックスを混和したポリマーセメン トモルタルの場合も, 酸の場合を除いて化学的腐食に対 する抵抗性を向上させることは可能であり, その化学的 腐食に対する評価は表-3のようにまとめられている ${ }^{20)}$ 。 表面被覆は, その定義は定かではないが樹脂の厚さに より, ライニング（約 $0.5 \mathrm{~mm}$ 以上）やコーティング （約 $1 \mathrm{~mm}$ 以上）に分類されている ${ }^{11}$ 。樹脂には不飽和 ポリエステル樹脂, エポキシ樹脂, ビニルエステル樹 脂, アクリル樹脂およびフラン樹脂などが使用されてい る。さらに混合する骨材の耐食性や耐摩耗性にも着目し セラミックス系の骨材を配合したものも使用されてい る。なお，コンクリートにモノマーを含浸させ, その後 重合させポリマー層を形成させた樹脂含浸コンクリート も化学的腐食抵抗性を有している ${ }^{21}$ 。最近埋設型枠など としての利用が盛んになっており，あらかじめ保護層と して利用することも有用である。

また，コンクリート施工時に型枠に設置し，図一9に 一例を示すように ${ }^{22}$, 裏面に有する突起部により硬化後 コンクリートと一体化するような塩化ビニールや高密度 ポリエチレンシートなども開発されている。ライニング やコーティングの場合にはピンホールなどの欠陥を生じ やすいが，これらの方法ではほぼ樹脂の性質を示す。こ の高密度ポリエチレンシートは優れた耐化学腐食性を示 し, 耐オゾン性やさらには耐摩耗性にも優れているとさ れている。なお, シートの接合部の評価やその方法につ いては十分な検討が必要であろう。

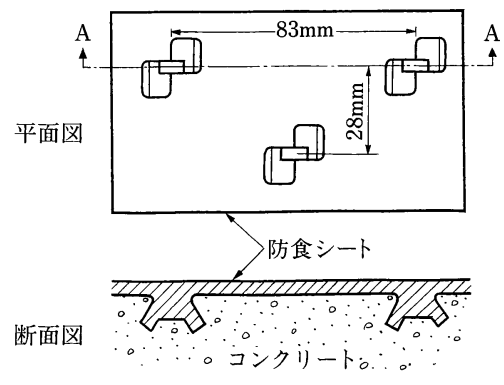

図-9＼cjkstart高密度ポリエチレンシートの形状

表-3 ポリマーセメントモルタルの耐薬品性の評価 (10 点法による評価)

\begin{tabular}{|c|c|c|c|c|c|}
\hline $\begin{array}{l}\text { ポリマーセメ } \\
\text { シトモルダ薬品の種類 }\end{array}$ & 酸 & アルカリ & 塩 & 溶 剂 & $\begin{array}{l}\text { 油脂 - } \\
\text { 鉱 油 }\end{array}$ \\
\hline 未 & 1 & $8 \sim 10$ & $1 \sim 7$ & $5 \sim 7$ & $7 \sim 10$ \\
\hline SBR 混 入 & $1 \sim 2$ & 10 & $5 \sim 10$ & $2 \sim 3$ & $8 \sim 10$ \\
\hline NBR 混 入 & $1 \sim 2$ & 10 & $5 \sim 10$ & 10 & 10 \\
\hline PAE 湿 入 & $1 \sim 2$ & 10 & $5 \sim 10$ & $2 \sim 3$ & $7 \sim 9$ \\
\hline EVA 混 入 & $1 \sim 2$ & $8 \sim 10$ & $5 \sim 10$ & $5 \sim 7$ & $8 \sim 10$ \\
\hline PVAC 混 入 & $1 \sim 2$ & $3 \sim 4$ & $3 \sim 7$ & $5 \sim 7$ & $8 \sim 10$ \\
\hline
\end{tabular}


樹脂についてはコンクリートのような耐用年数を耐候 性の観点から要求することは不可能であり, またそれら の観点からのデータの蓄積も少ないので, ある程度定期 的な補修を予め計画することが必要であろう。

\section{4.おわりに}

化学的腐食に対する対策としては，ひび割れの少ない 密実なコンクリートを施工することは言うまでもないこ とである。しかし, 化学的腐食を受ける構造物の増大や またその腐食因子も多種になり, 複合的な化学腐食や他 の劣化要因との組み合わせも増大している。このような 場合には, ポルトランドセメント系でない結合材の利用 や樹脂での表面被覆などでの対応が必要と思われる。化 学的腐食に対する抵抗性を高めた非ポルトランドセメン 卜系は他の性質においては欠点を有しているものもあ り，それらを十分配慮して使用する必要がある。また， 樹脂に関しては従来考慮されていた耐用年数がセメント コンクリートと比べると非常に短く, また, 劣化した後 の補修がしにくいなどの欠点もある。完全に化学的腐食 を受けない材料の開発をめざすことは言うまでもないこ とであるが, 補修しやすい材料であるポルトランドセメ ント系のコンクリートを使用し，計画的な補修をしてい くような利用方法も重要と思われる。そのためには, 種々の化学的腐食の機構やそれらに対するコンクリート の耐用年数などを整理していく必要がある。なお，今回 の概説には含まれていないコンクリートの複合的劣化に ついても考慮することが重要である。

〈参考文献〉

1) 小林一輔 : コンクリート構造物の早期劣化と耐久性診 断, 森北出版, 1991

2) 森 忠洋: コンクリート構造物の微生物腐食, 用水と廃 水, 31, pp. 3-6, 1989

3）水上国男：化学的腐食，技報堂出版，1986

4) 坂井悦郎, 中谷清一, 真下昌章, 大門正機 : 石膏と石 灰, No. 249, pp. 115-121 (1994)

5）セメント協会耐久性専門委員会 : コンクリートに及ぼす
酸性雨の影響, セメント・コンクリート, No. 569, pp. 25-35 (1994)

6) 坂井悦郎：耐硫酸塩性，セメント・コンクリート, No. 517, pp. 46-47, 1990

7）小林和一，岡林茂生：セメント技術年報， 29, pp. 66-70 (1975)

8）鳥居和之, 川村満紀, 山田正弘, S. Chatterji :セメン ト・コンクリート論文集, No. 46, pp. 504-509, 1992

9) 大門正機, 坂井悦郎他 : 高炬スラグ微粉末を混合したセ メント硬化体の炭酸化反応, 第 21 回セメント・コンク リート研究討論会論文報告集, pp. 29-34, 1994

10）大門正機, 坂井悦郎他 : 各種水和物の炭酸化反応, 無機 マテリアル印刷中

11）中本 至: 下水道施設におけるコンクリート構造物の化 学的劣化, 土木学会論文集, No. 472, V -20, pp. 1-11, 1993

12）鐵鋼スラグ協会 : 鉄鋼スラグの高炉セメントへの利用に ついて, 1985

13) 坂井悦郎：シリカフューム, 月刊生コンクリート, 9 (11), pp. 125-131, 1990

14）長滝重義, 坂井悦郎 : 超高強度コンクリートの製造と用 途, コンクリート工学, 25 (8), pp. 15-23, 1987

15）富田六郎：低収縮セメント, セメント・コンクリート, No. 535, pp. 33-37, 1991

16) J.P. Bayoux, J.P. Letourneux, S. Marcdargent : Acidic corrosion of high aluminia cement, Proc. Int'l Symp. Calcium Aluminate Cements, pp. 230-240, 1990

17) W.G. Piasta : The effect of limestone fillers on sulphate resistance of high alumina cement compositers, 同上, pp. 241-255

18）飯田達郎, 三原敏夫, 石膏と石灰, No. 222 , pp. 251255,1989

19）西 晴哉, 水上国男, 田辺正人, 今井友宏 : 硫黄コンク リートの諸性状，セメント技術年報，37, pp. 533-537， 1983

20）大浜嘉彦: ポリマー混和材, 新・コンクリート用混和材 料, シーエムシー, pp. 199-216, 1988

21）堀島壽平, 田沢栄一 : 樹脂モノマー含浸セメント製品の 物性, 最近のセメント・コンクリート製品, $71-72$, pp. 147-159, 1972

22）堅川孝生，西村清一，山中治明：高密度ポリエチレン製 シートを用いた防食工法の開発, コンクリート工学年次 論文報告集, Vol. 16, pp. 847-852, 1994

\title{
炭酸化を受けたコンクリート構造物の判定マニュアル
}

\author{
A 4 判・ 42 ページ（カラー写真 6 ページを含む） \\ 定価 4500 円 (税远), 会員特価 4000 円 (税这) / 送料 300 円
}

- 申込先 : (社) 日本コンクリート工学協会・管理課「書籍販売係」

干102 千代田区麦町 5-7 TBR 708 号/電話 (03) 3263-1571（担当: 宇野)

〈申込方法〉 書籍名・送付先を明記のうえ，前金（現金書留）にてお申込み下さい。 